\title{
The Role of Head Nurse, Critical Thinking Nurse and Documentation of Integrated Patient Progress Note: Cross Sectional
}

\author{
Dwi Nopriyanto $^{1 *}$, Ruminem$^{1}$, Mayusef Sukmana ${ }^{1}$, Timmy Emelia $^{2}$ \\ ${ }^{I}$ Mulawarman Universiy Samarinda, Indonesia \\ ${ }^{2}$ RSUD. I.A Moeis Samarinda, Indonesia \\ *d.nopriyanto@yahoo.co.id
}

\begin{abstract}
Documentation problems occur due to inadequate supervision when documenting nursing, problems of competence in documentation, lack of confidence and motivation, reasoning skills and the application of professional standards. Documenting patient development in accordance with the rules of writing requires high complexity so critical thinking is needed for a nurse, as well as the role of head nurse as a manager able to have a positive impact on the implementation of documentation carried out by implementing nurses.

The study aimed to identify the relationship between the role of head nurse and critical thinking of nurse to the documentation of integrated patient progress note.

The study used a descriptive correlation design, a cross sectional approach, with a sample of 69 nurses who documented integrated patient pogress note, using cluster sampling techniques, through Pearson, Spearman, Mann Whitney and Linear Regression analyzes.

There was a significant relationship between the role of head nurse $(p=0.038 ; \alpha=0.05)$ and the nurse's critical thinking ( $p=0.003 ; \alpha=0.05)$ to the documentation of integrated patient progress note. Critical thinking of nurses is the most influential factor in documenting integrated patient progress note.

Here needs to be a policy, evaluation and monitoring of the nursing manager through selfdevelopment in the application the role of head nurse, critical thinking of nurse and the implementation of documentation of integrated patient progress note.
\end{abstract}

Keywords:Critical thinking of nurse, Patient progress note, Role of head nurse 


\section{STRADA Jurnal Ilmiah Kesehatan}

DOI: $10.30994 /$ sjik.v9i2.293

ISSN: 2252-3847 (print); 2614-350X (online)

Vol.9 No.2 November 2020 Page.316-324

\section{BACKGROUND}

Nursing documentation is written communication, where nursing documentation is a very important process in nursing practice and contributes to patient health and safety, facilitating communication between nurses and other health care providers(Ioanna, Stiliani, \& Vasiliki, 2007; John \& Bhattacharya, 2016). Nurses are estimated to spend around 15\% - $25 \%$ of shift time to document patient care (Wang, Hailey, \& Yu, 2011), or spend around 117 minutes in each shift(Hariyati, Yani, Eryando, Hasibuan, \& Milanti, 2015).

Clinical mismanagement that occurs around $20.7 \%$ comes from weighing in patients and $3.7 \%$ relates to communication in patient records/documentation that occurs in hospitals (Habermann, Foraita, \& Cramer, 2013). Completeness of the documentation ranges from $85 \%$, where $71.6 \%$ is incomplete and around $28.4 \%$ is written in full, making the information submitted related to patient care and health conditions will be ignored(Siswanto, Hariyati, \& Sukihananto, 2013). Documentation problems occur due to inadequate supervision of nursing documentation, problems of competence in documentation, lack of confidence and motivation(Kamil, Rachmah, \& Wardani, 2018), reasoning skills and the application of professional standards(Deniati, Anugrahwati, \& Suminari, 2018).

Documentation of patient development in accordance with the rules of writing requires high complexity so that critical thinking is needed for nurses, the accuracy of nursing care that is enforced is related to the critical thinking skills possessed by nurses(Kelly, Dias, \& Crossetti, 2013; Lunney, 2010).Critical thinking nurse have 2.403 times the ability to perform nursing care well when compared to nurses who lack critical thinking (Deniati et al., 2018). Whereas the role of head nurses as a manager will have a positive impact on the implementation of documentation carried out by implementing nurses, where a good relationship will provide assistance and support to provide effective nursing services (Blair \& Barbara Smith, 2012; Braaf, Manias, \& Riley, 2011; Staskova, Vankova, Tothova, \& Bartlova, 2015). Therefore, this study is important to look at the relationship between the role of head nurse and the critical thinking of nurse can influence the implementation of patient development documentation in the ward.The study aimed to identify the relationship between the role of head nurse and critical thinking of nurse to the documentation of integrated patient progres note

\section{METHODS}

This study uses a descriptive correlation design using a cross-sectional approach. The population in this study were implementing nurses working in the inpatient room and documentation of integrated patient development records conducted by nurses. The sampling technique for nurse samples with probability sampling, using cluster sampling method. The sample in this study amounted to 69 nurses who were in 3 ward of X Samarinda Hospital. This research was carried out for 6 weeks. Data collection in this study used 2 questionnaires (the Role of Head nurse and Critical Thinking of Nurse) as well as an observation sheet to assess the implementation of documentation of integrated patient development records conducted by nurses. The data obtained were then analyzed using the SPSS program using statistical tests of Pearson, Spearman, Mann Whitney and Linear Regression analyzes.Before this research was conducted, researchers had conducted an ethics review test with letter number No: 156/KEPK-FK/X/2019 at the Faculty of Medicine, University of Mulawarman and was declared graduated. 


\section{STRADA Jurnal Ilmiah Kesehatan}

DOI: $10.30994 /$ sjik.v9i2.293

ISSN: 2252-3847 (print); 2614-350X (online)

Vol.9 No.2 November 2020 Page.316-324

\section{RESULTS}

Tabel 1 An Overview of the Role of Head Nurse and Critical Thinking of Nurse perceived by the room nurse at Hospital X Samarinda October - November 2019 (n=69)

\begin{tabular}{lcccc}
\hline \multicolumn{1}{c}{ Variabel } & Mean & Min -Max & $\begin{array}{c}\text { Standar } \\
\text { Deviasi }\end{array}$ & 95\% CI \\
\hline The Role of Head Nurse & 53,94 & $44-64$ & 5,104 & $52,72-55,17$ \\
Critical Thinking of Nurse & 111,96 & $78-129$ & 8,797 & $109,84-114,67$ \\
\hline
\end{tabular}

Tabel 1 explains the average description of the role of head nurse perceived by nurses is $53,94(84.28 \%)$. The value of the role of head nurse perceived by nurses is the lowest 44 and the highest value is 64 . While the average value of critical thinking nurse is 111,96 (84.82\%), while the lowest value of critical thinking of nurse is 78 and the highest value is 129 .

Tabel 2 Overview Documentation of Integrated Patient Progress Note Conducted by a Nurse in the Hospital X Samarinda, October - November 2019 ( $\mathrm{n}=67$ )

\begin{tabular}{lrlcc}
\hline \multicolumn{1}{c}{ Variabel } & Mean & Min -Max & $\begin{array}{c}\text { Standar } \\
\text { Deviasi }\end{array}$ & 95\% CI \\
\hline $\begin{array}{l}\text { Documentation of } \\
\text { Integrated Patient Progress } \\
\text { Note }\end{array}$ & 30,46 & $25-36$ & 2,604 & $29,84-3,09$ \\
\hline
\end{tabular}

Tabel 2 explains the average description of the documentation of integrated patient progress note by nurses is 30,46 (72.52\%). The value of documenting integrated patient progress note carried out by nurses the lowest value is 25 and the highest value is 36 .

Tabel 3 Relationship of Characteristics (sex, education and employement status) with Documentation of Integrated Patient Progress Note at Hospital X Samarinda October November $2019(\mathrm{n}=69)$

\begin{tabular}{|c|c|c|c|c|}
\hline \multirow{2}{*}{ Variabel } & \multicolumn{4}{|c|}{$\begin{array}{c}\text { Documentation of Integrated Patient } \\
\text { Progress Note }\end{array}$} \\
\hline & $\mathbf{N}$ & Mean & $\begin{array}{l}\text { Standar } \\
\text { Deviasi }\end{array}$ & $p$ \\
\hline & \multicolumn{4}{|c|}{ Gender } \\
\hline$\overline{\text { Male }}$ & 14 & 31,29 & 2,128 & \multirow{2}{*}{0,137} \\
\hline \multirow[t]{2}{*}{ Famale } & 55 & 32,02 & 1,939 & \\
\hline & \multicolumn{4}{|c|}{ Education } \\
\hline Nursing Diploma & 59 & 31,81 & 2,021 & \multirow{2}{*}{0,567} \\
\hline \multirow[t]{2}{*}{ Nurse } & 10 & 32,20 & 1,814 & \\
\hline & \multicolumn{4}{|c|}{ Employment status } \\
\hline Government employees & 20 & 31,35 & 1,755 & \\
\hline $\begin{array}{l}\text { Non-government } \\
\text { employees }\end{array}$ & 49 & 32,08 & 2,050 & 0,136 \\
\hline
\end{tabular}




\section{STRADA Jurnal Ilmiah Kesehatan}

DOI: $10.30994 /$ sjik.v9i2.293

ISSN: 2252-3847 (print); 2614-350X (online)

Vol.9 No.2 November 2020 Page.316-324

Tabel 3 shows that there was no significant relationship based on sex , education and employment status in documenting of integrated patient progress note $(p>0.05)$. For the level of education although there is no significant relationship, the average value of nurses with a Nurse education is higher (32.30) than nursing diploma (D3) (31.81) in the documentation of integrated patient progress note.

Tabel 4 Relationship of Characteristics (age and work experience) with Documentation of Integrated Patient Progress Note at Hospital X Samarinda October-November 2019 (n = 69)

\begin{tabular}{lcc} 
Variabel & \multicolumn{2}{c}{ Progress Note } \\
\cline { 2 - 3 } & \multicolumn{1}{c}{ r } & $\boldsymbol{p}$ \\
\hline Age & 0,100 & 0,414 \\
\hline Work Experience & 0,044 & 0,722 \\
Signifikan one tailed $\alpha=0,05$ & &
\end{tabular}

Tabel 4 shows a positive relationship but does not describe a significant relationship between age and length of work with documentation of integrated patient progress note with $\mathrm{r}=0.100$ and 0.044 and $(p>0,05)$.

Tabel 5 Relationship between the Role of Head Nurse and Nurse Critical Thinking with Documentation of Integrated Patient Progress Note at Hospital X Samarinda OctoberNovember $2019(n=6$

\begin{tabular}{lcc}
\hline \multirow{2}{*}{ Variabel } & \multicolumn{2}{c}{$\begin{array}{c}\text { Documentation of Integrated Patient } \\
\text { Progress Note }\end{array}$} \\
\cline { 2 - 3 } & $\mathbf{r}$ & $\boldsymbol{p}$ \\
\hline The Role of Head Nurse & 0,250 & $0,038^{*}$ \\
\hline Critical Thinking Nurse & 0,349 & $0,003^{*}$ \\
\hline
\end{tabular}

Tabel 5 explains that there is a significant relationship and has a positive correlation between the role of head nurse and the documentation of integrated patient progress note, with $p$ values $<0.05$ and $r=0.260$. As well as explaining that there is a significant relationship and having a positive correlation between nurses' critical thinking and documenting integrated patient progress note, with $p$ values $<0.05$ and $r=0.349$.

Tabel 6 Multivariate Regression of Documentation of Integrated Patient Progress Note at Hospital X Samarinda 


\section{STRADA Jurnal Ilmiah Kesehatan}

DOI: $10.30994 /$ sjik.v9i2.293

ISSN: 2252-3847 (print); 2614-350X (online)

Vol.9 No.2 November 2020 Page.316-324

\begin{tabular}{lcccccc}
\hline \multicolumn{1}{c}{ Variabel } & $\mathbf{B}$ & $\mathbf{S E}$ & Beta & $\mathbf{R}$ & $\mathbf{R}^{\mathbf{2}}$ & $\boldsymbol{p}$ \\
\hline Constan & 19.734 & 3.409 & & 0.420 & 0.177 & 0.000 \\
\hline Gander & 0.418 & 0.581 & 0.085 & & & 0.474 \\
\hline Education & 0.316 & 0.325 & 0.111 & & & 0.344 \\
\hline Employment status & 0.730 & 0.513 & 0.168 & & & 0.160 \\
\hline The Role of Haed Nurse & 0.040 & 0.050 & 0.104 & & 0.424 \\
\hline Critical Thinking Nurse & 0,067 & 0.029 & 0.299 & & & 0.021
\end{tabular}

Tabel 6 results of the linear regression equation explains the most influential factor in the implementation of documentation of integrated patient progress note performed by nurses is the critical thinking skills seen from the beta value of 0.299 .

\section{DISCUSSION}

The results of the study prove the role of the head nurse (the role of information, interpersonal relations and in the decisional) has a significant relationship to the implementation of documentation of integrated patient progress note $(p=0.038)$. The role of head nurse as the room manager will increase coordination between service providers in the ward. The role of a leader is not only able to increase the confidence of nurses but also can improve the ability of the workplace (Salanova, Lorente, Chambel, \& Mart1, 2011). The ability of nurses in documenting integrated patient progress note is a process of behavior change carried out by the head nurse as a line manager. This process of behavior change does not occur instantly, there are three components that must be seen from Bandura's theory, namely from the behavior of the model, the influence of the behavior of the model and internal processes(Surya, 2004). Where the nurse performs behavior changes following the behavior of the person giving the example. Improving nursing documentation involves complex challenges in the setting and demands a variety of approaches.

Controlling, mentoring and periodic supervision as well as motivation from the head nurses as a manager in carrying out his role will be able to influence and improve the implementation of documentation of patient integrated progress note according to the principles and rules of writing. The head nurse as a manager has expertise through knowledge, the role of information providers, interpersonal relationships and in the role of deciding(Robbins, \& Judge, 2013). The process of teaching by a manager and nurse can increase the knowledge and skills of a nurse. Learning behavior impacts the contribution in work behavior, learning behavior that is different and has different possibilities at the organizational level(Spânu et al., 2013). The role of the head nurses as a manager for implementing nurses will be able to be implemented to the maximum and will be able to improve dynamic relationships. Leadership and skills performed by a nursing manager directly impacts the outcome of thepatient(Witges \& Scanlan, 2014). The role of a nursing unit manager is very important. They will influence the work of nurses by ensuring a positive work environmen(Duffield, Roche, O’Brien-Pallas, Catling-Paull, \& King, 2009).

Implementation of integrated patient progress note documentation in accordance with the procedures for writing is a relationship of the role of head nurse who carry out his role as a manager. Where interdependent dependence between two or more individuals to influence each other with a particular purpose by involving social and emotional ability. A head nurses also needs to participate in making a decision and they must be trained in the involvement of nurses in decision making(Ahmed \& Safadi, 2013). The role of head nurse 


\section{STRADA Jurnal Ilmiah Kesehatan}

DOI: $10.30994 /$ sjik.v9i2.293

ISSN: 2252-3847 (print); 2614-350X (online)

Vol.9 No.2 November 2020 Page.316-324

as a line manager can influence a nurse in the implementation of documentation. increasing the ability of the implementing nurse is significant in documenting integrated patient progress note through implementation in the form of strengthening the role of head nurse(Nopriyanto, Hariyati, \& Ungsianik, 2019). The leadership role of head nurse and having innovative behavior and communication skills will be easier in dealing with nurses(Arif, Zubair, \& Manzoor, 2006). This behavior can motivate someone to do what is expected from the organizational goals. Motivation provided by a person is an effort to provide staff job satisfaction. A positive attitude, enthusiasm and productive and carrying out good activities are the role models of a head nurse as a manager.

Managerial nurses (head nurse) and implementing nurses require more participation in decision making than those who are already trained(Ahmed \& Safadi, 2013). Because a manager must be able to become an agent of reform, manage and take advantage of opportunities to improve the quality of nursing services in the nursing room, especially in the implementation of documentation. To achieve better documentation, required more extensive changes, including building a large number of competent staff, redesigning the orientation and continuing education, redesign the form of documentation, changes in the mix of skills of nurses, and support the leadership of sustainable(Okalsu, Kalikwani, Wanyana, \& Coetzee, 2014).

In the study also found a significant relationship between nurses' critical thinking on the implementation of documentation of integrated patient development records ( $p=0.003)$. The use of integrated documentation records for nurses is proof that nurses are able to think critically understand and are able to fulfill obligations in the implementation of care, where nurses ensure effective service throughout the patient care room. Nurses who think critically are able to perform nursing care well when compared to nurses who lack critical thinking(Deniati et al., 2018). Nurses who are able to think critically consistently are able to produce useful insights and are the basis of rational thinking(Facione, 2013).

Critical thinking goes beyond all other domains that are inseparable from the responsibilities and duties of health care providers and has the potential to influence patient care outcomes. Therefore, the ability to identify learners' challenges and guidance in developing competencies must be the focus of more attention for educators in nursing and medicine(Papp et al., 2014).

Nursing activities are very important in the hospital and must solve the problems needed by patients. Every nursing activity must produce documentation with critical thinking. If nursing documents are unclear and accurate, communication between professionals and evaluation of nursing care cannot be optimal(Asmirajanti, Hamid, \& Hariyati, 2019). Nursing activities and documentation must be directed, controlled, and evaluated continuously by the nurse manager. The quality of nursing activities must always be good to increase patient satisfaction, patient safety, and cost effectiveness(Asmirajanti et al., 2019).

The results showed that gender, nurse education staffing status, the role of head nurse and critical thinking of nurse can predict the implementation of integrated patient progress note by nurses at Samarinda Hospital X by $17.7 \%$ and the rest is controlled by other factors.Factors that greatly affect the implementation of documentation of integrated patient progress note carried out by nurses at Samarinda Hospital X is the nurse's critical thinking skills can be seen from the beta value of 0.299 , meaning that the greater the beta value, the greater the effect on the dependent variable namely the documentation of patient 


\section{STRADA Jurnal Ilmiah Kesehatan}

DOI: $10.30994 /$ sjik.v9i2.293

ISSN: 2252-3847 (print); 2614-350X (online)

Vol.9 No.2 November 2020 Page.316-324

development records integrated. Critical thinking in nursing experiences a growing interest in the study of concepts and dimensions, as well as in the development of training strategies to advance its development among professionals(Perez et al., 2014). The ability of nurses to identify client problems and choose the right intervention solution is inseparable from the nurse's ability to think critically in exploring various reasons based on the evidence baseof each problem and identified solutions (Potter \& Perry, 2010). Nurses with good critical thinking skills will realize their role and self-identity in relation to matters in carrying out integrated patient progress note documentation.

Critical thinking is important for nurses to make before making decisions in nursing care, because critical thinking in nursing is a nurse's thinking skills to test various reasons rationally before making decisions in nursing care so that nursing care provided will be maximal and far better (Deniati et al., 2018). To improve these skills nurses need to develop critical thinking skills using appropriate strategies (Salehi \& Bahrami, 2015). Efforts to improve critical thinking skills by creating an organizational culture that supports nurses to develop themselves, increase nurse confidence, communication skills, reward systems, supervision, provide motivation and support comprehensively(Ardian, Hariyati, \& Afifah, 2019). With the efforts made, it will improve the ability of implementing nurses in the implementation of documentation of integrated patient progress note at Samarinda's X Hospital.

\section{CONCLUSION}

The results explained that there was a relationship between the role of head nurse with the documentation of integrated patient progress note, as well as the relationship between the nurse's critical thinking with the documentation of integrated patient progress note. The most influential factor in the implementation of documentation of integrated patient progress note at Samarinda Hospital $\mathrm{X}$ is the critical thinking of nurses after being contacted by factors of gender, education, employment status and the role of head nurse.

The results also showed no relationship between nurse characteristics (age, work experience, sex, education and employment status) with the implementation of integrated patient progress note documentation. But nurses with nurse educating have a higher mean of documenting than nurses with a nursing diploma.

It is necessary to have a policy, evaluation and monitoring of nursing managers through self-development in the application of the role of head nurses, critical thinking of nurses and the implementation of documentation of integrated patient progress note. As well as providing program facilities starting from preparation. Preparation can begin with making a decision letter, guidebooks, standard operating procedures (SPO), logbooks, and other supporting facilities such as discussion rooms.

\section{ACKNOWLEDGMENTS}

The researchers would like to thank nurses for their participantion in this study.

\section{REFERENCES}

Ahmed, M. Z., \& Safadi, E. G. (2013). Decisional involvement among nurses: Governmental versus private hospitals. Health Science Journal, 7(1), 18-27.

Ardian, P., Hariyati, R.T.S, \& Afifah, E. (2019). Correlation between implementation case reflection discussion based on the Graham Gibbs Cycle and nurses ' critical thinking skills $\quad$ E. Enfermería Clínica, 29, 588-593. 


\section{STRADA Jurnal Ilmiah Kesehatan}

DOI: $10.30994 /$ sjik.v9i2.293

ISSN: 2252-3847 (print); 2614-350X (online)

Vol.9 No.2 November 2020 Page.316-324

https://doi.org/10.1016/j.enfcli.2019.04.091

Arif, S., Zubair, A., \& Manzoor, Y. (2006). Innovative Work Behavior and Communication Climate among Employees of Advertising Agencies. Sbbwu.Edu.Pk,

9. Retrieved from http://sbbwu.edu.pk/downloads/nine.pdf

Asmirajanti, M., Hamid, A. Y. S., \& Hariyati, R. T. S. (2019). Nursing care activities based on documentation. BMC Nursing, 18(Suppl 1), 1-5.

Blair, W., \& Barbara Smith. (2012). Nursing Documentation: Framewor and Barriers. Contemporary Nurse, 41(2), 160-168.

Braaf, S., Manias, E., \& Riley, R. (2011). The role of documents and documentation in communication failure across the perioperative pathway. A literature review. International Journal of Nursing Studies, 48(8), 1024-1038. https://doi.org/10.1016/j.ijnurstu.2011.05.009

Deniati, K., Anugrahwati, R., \& Suminari, T. (2018). Pengaruh berpikir kritis terhadap kemampuan perawat pelaksaana dalam melakukan auhan keperawatan di rumah sakit Hermina Bekasi Tahun 2016. Jurnal Kesehatan Holisttik (The Journal of Holistic Healthcare), 12(1), 21-25.

Duffield, C., Roche, M., O’Brien-Pallas, L., Catling-Paull, C., \& King, M. (2009). Staff satisfaction and retention and the role of the Nursing Unit Manager. Collegian, 16(1), 11-17. https://doi.org/10.1016/j.colegn.2008.12.004

Facione, P. A. (2013). Critical Thinking : What It Is and Why It Counts. Milibrae.

Habermann, M., Foraita, R., \& Cramer, H. (2013). Categories of errors and error frequencies as identified by nurses: Results of a cross-sectional study in German nursing homes and hospitals. Journal of Public Health (Germany), 21(1), 3-13. https://doi.org/10.1007/s10389-012-0531-x

Hariyati, R.T.S., Yani, A., Eryando, T., Hasibuan, Z., \& Milanti, A. (2015). The Effectiveness and Efficiency of Nursing Care Documentation Using the SIMPRO Model. International Journal of Nursing Knowledge, (January 2016). https://doi.org/10.1111/2047-3095.12086

Ioanna, P., Stiliani, K., \& Vasiliki, B. (2007). Nursing documentation and recording systems of nursing care. Healt Science Journal, (4).

John, S. K., \& Bhattacharya, P. C. (2016). Documentation guidelines based on expectation of documentation helps accurate documentation among nurses in psychiatric settings. Asian J. Nursing Edu and Research, 6(June), 260-265. https://doi.org/10.5958/23492996.2016.00050.1

Kamil, H., Rachmah, R., \& Wardani, E. (2018). What is the problem with nursing documentation? Perspective of Indonesian nurses. International Journal of Africa Nursing Sciences, 9(December 2017), 111-114. https://doi.org/10.1016/j.ijans.2018.09.002

Kelly, G., Dias, G., \& Crossetti, O. (2013). Critical thinking skills in the nursing diagnosis process. Scielo Journal, 47(2), 337-343.

Lunney, M. (2010). Use of Critical Thinking in the Diagnostic Process. International Journal of Nursing Terminologies and Classifications,21(2), 82-88. https://doi.org/10.1111/j.1744-618X.2010.01150.x

Nopriyanto, D., Hariyati, R.T.S.., \& Ungsianik, T. (2019). Improving documentation of patient progress note through role empowerment of head nurse by Orlando theory approach $\quad$ E. Enfermería Clínica, 29, 182-188. https://doi.org/10.1016/j.enfcli.2019.04.051 


\section{STRADA Jurnal Ilmiah Kesehatan}

DOI: $10.30994 /$ sjik.v9i2.293

ISSN: 2252-3847 (print); 2614-350X (online)

Vol.9 No.2 November 2020 Page.316-324

Okalsu, E. ., Kalikwani, F., Wanyana, G., \& Coetzee, M. (2014). Improving the quality of nursing documentation: An action research project, 38(1), 1-11. https://doi.org/10.4102/curationis.v37i1.1251

Papp, K. K., Huang, G. C., Clabo, L., Delva, D., Fischer, M., Konopasek, L., ... Gusic, M. (2014). Milestones of critical thinking: A developmental model for medicine and nursing. Journal of the Association of American Medical Colleges,89(5), 715-720. https://doi.org/10.1097/ACM.0000000000000220

Perez, E., Canut, M., Pegueroles, A., Liobet, M., Arroyo, C., \& Mrino, J. (2014). Critical thinking in nursing: Scoping review of the literature. International Journal of Nursing Practice, 21(6), 820-830. https://doi.org/10.1111/ijn.12347

Potter, P. ., \& Perry, G. . (2010). Fundamental of nursing (7th ed.). St. Louis: Mosbay Elsevier.

Robbins, P.S \& Judge, A. . (2013). Organizational Behavior (15th ed.). Boston: Pearson.

Salanova, M., Lorente, L., Chambel, M. J., \& Mart1, I. M. (2011). Linking transformational leadership to nurses' extra-role performance: the mediating role of self-efficacy and work engagement. Journal of Advanced Nursing, 2256-2266. https://doi.org/10.1111/j.1365-2648.2011.05652.x

Salehi, S., \& Bahrami, M. (2015). Critical Thinking and Clinical Decision Making in Nurse. Iranian Journal of Nursing and Midwifery Research, 12(September 2014), 1316.

Siswanto, L. M. H., Hariyati, R. T. S., \& Sukihananto. (2013). Faktor-Faktor Yang Berhubungan Dengan Kelengkapan Pendokumentasian Asuhan Keperawatan. Jurnal Keperawatan Indonesia, 16(2), 77-84. https://doi.org/pISSN 1410-4490, eISSN 2354-9203

Spânu, F., Băban, A., Bria, M., Lucăcel, R., Florian, I. Ş., \& Rus, L. (2013). Error Communication and Analysis in Hospitals: The Role of Leadership and Interpersonal Climate. Procedia - Social and Behavioral Sciences, 84(0), 949-953. https://doi.org/http://dx.doi.org/10.1016/j.sbspro.2013.06.680

Staskova, V., Vankova, M., Tothova, V., \& Bartlova, S. (2015). Reference to the human to human relationship concept in the work of Joyce Travelbee and its potential application regarding supervision in nursing. Journal of Nursing, Social Studies, Public Health and Rehabilitation, 3(4), 130-134.

Surya, M. (2004). Psikologi Pembelajaran dan Pengajaran. Bandung: Pustaka Bani Quraisy.

Wang, N., Hailey, D., \& Yu, P. (2011). Quality of nursing documentation and approaches to its evaluation: A mixed-method systematic review. Journal of Advanced Nursing, 67(9), 1858-1875. https://doi.org/10.1111/j.1365-2648.2011.05634.x

Witges, K. A., \& Scanlan, J. M. (2014). Understanding the role of the nurse manager: The full-range leadership theory perspective. Nurse Leader, 12(6), 67-70. https://doi.org/10.1016/j.mnl.2014.02.007 